\title{
Dispersed plant mesofossils from the Permian of Wuda, Inner Mongolia, Taiyuan Formation, China
}

\author{
Zbyněk Šimůnek ${ }^{1}$ and Jan Bureš ${ }^{2}$ \\ ${ }^{1}$ Czech Geological Survey, Klárov 131/3, 11821 Praha 1, Czech Republic; (zbynek.simunek@geology.cz) \\ 2 West Bohemian Muzeum Plzeň, Kopeckého sady 2, 30100 Plzeň, Czech Republic; (rallus@seznam.cz)
}

doi: $10.4154 / g c .2019 .17$

Article history:

Manuscript received January 31, 2019

Revised manuscript accepted September 23, 2019

Available online October 31, 2019

Keywords: Dispersed cuticles, Permian, Wuda, China, conducting tissue

\begin{abstract}
A coal sample from the Lower Permian Taiyuan Formation (Wuda locality, Inner Mongolia, China) was macerated. It yielded two cuticle fragments and many fragments of conducting tissue. One cuticle fragment shows strongly corroded polygonal cells belonging either to a pteridosperm or a cycad. The second fragment is an abaxial cordaitalean cuticle with papillate tetragonal cells and can be compared to Cordaites neimengensis LIU et al. 1998. The conducting tissue are represented by biseriate to quadriseriate tracheid pitting that is typical for cordaitaleans.
\end{abstract}

\section{INTRODUCTION}

The first author obtained a tuff sample containing remains of Cordaites leaves from J. VOTOČKOVÁ-FROJDOVÁ and M. LIBERTÍN. One side was attached to a thin layer of coal from the uppermost part of Coal Seam 7. This coal sample was macerated with the aim of obtaining dispersed cuticles. Although the resulting dispersed cuticle assemblage was not very rich, many conducting tissue remains were obtained, the results of which are summarised here.

\section{GEOLOGICAL SETTING}

The studied locality is at N $39^{\circ} 28^{\prime} 53^{\prime \prime}$, E $106^{\circ} 38^{\prime} 08^{\prime \prime}$ in the Wuda Coal District near the city of Wuda in the Inner Mongolia (Nei Mongol) Autonomous Region of Northern China (Fig. 1). The Wuda District lies in the northwestern foothills of the Helan Shan Mountain Chain with elevations of over 3,000 m. The locality has an elevation of around 1,270 m (PFEFFERKORN \& WANG, 2007) and the rocks are well exposed due to the dry climate and the lack of any continuous soil or plant cover.

The studied coal sample came from the uppermost part of Coal Seam 7, which belongs to the Taiyuan Formation and is separated from the overlying Coal Seam 6 of the Shanxi Formation by a tuff layer (Fig. 2). Both coal seams are of Early Permian age.

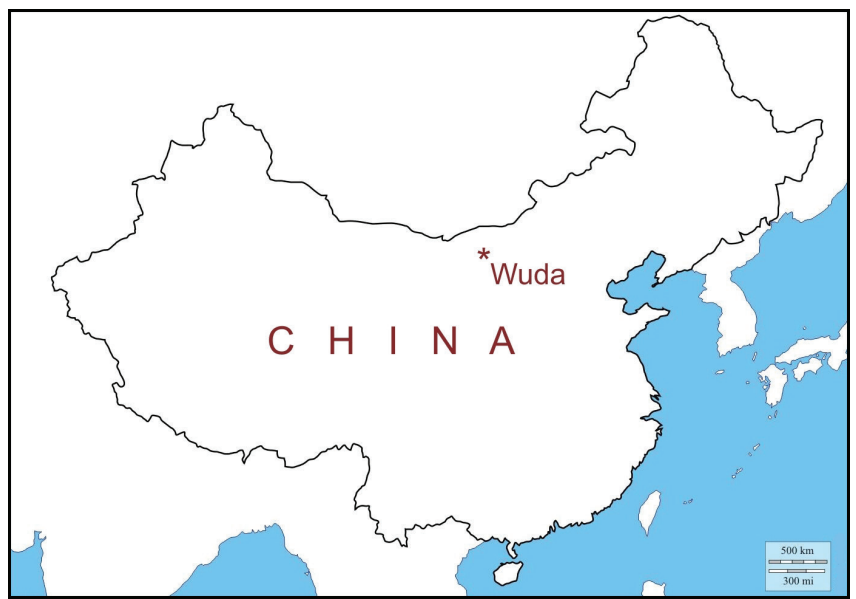

Figure 1. Location of the Wuda locality in China.

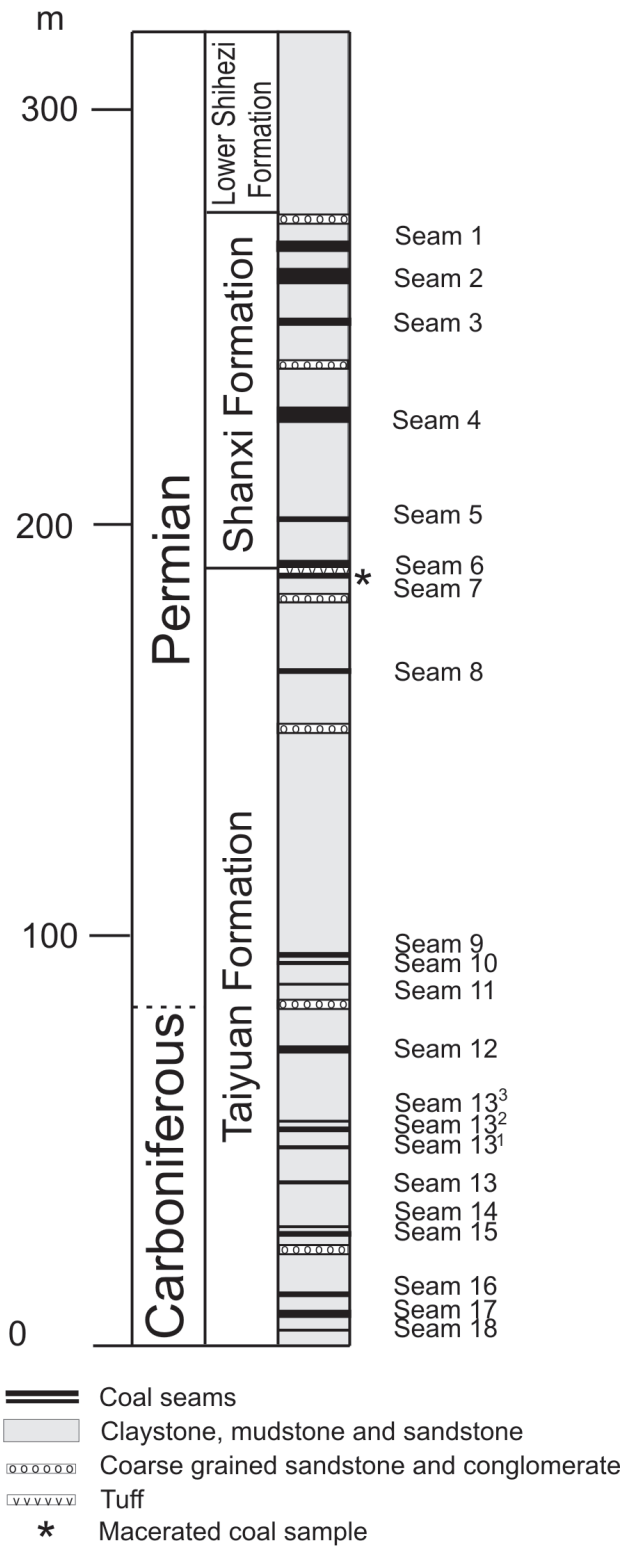

Figure 2. Stratigraphic section in the Wuda Coal Mine. Modified from WANG et al. (2007). 
Both the Taiyuan and the Shanxi formations consist of coarse to fine clastic beds and coals that were deposited in fluvial, lacustrine and paludal environments (PFEFFERKORN \& WANG, 2007). The basal part of the Taiyuan Formation is Carboniferous (Stephanian, Gzhelian) in age. The youngest strata in the section belong to the coal-barren Lower Shihezi Formation (Fig. 2). Geotectonically the area is part of the northwestern margin of the North China Plate. Palaeobiogeographically, the flora belongs to the North China phytogeographic area (SHEN, 1995; WANG \& SHEN, 1996; SHEN et al., 1996; WANG et al., 1999). The Early Permian plants of this area are generally quite similar to those of central North China (HALLE, 1927; LEE, 1963; HE et al., 1995).

\section{MATERIAL AND METHODS}

The sample investigated was a coal attached to a tuff sample containing Cordaites remains from the top of the Coal Seam 7 in the Wuda coal opencast mine and belonged to the Lower Permian, Taiyuan Formation. The sample was collected by VOTOČKOVÁFROJDOVÁ and LIBERTÍN during excavations with Chinese colleagues in the Quadrant 8D in 2016.

To obtain the mesofossils, the authors used the same method as in ŠIMŮNEK \& BUREŠ (2015): A 5 g sample of coal was macerated in $35 \mathrm{ml}$ of concentrated $(65 \%)$ nitric acid $\left(\mathrm{HNO}_{3}\right)$ for 2 days and 22 hours. The black residue was fully washed under running water in a sieve and then treated with $10 \%$ potassium hydroxide $(\mathrm{KOH})$ for up to one hour. During this process, the coal matter was mostly dissolved and cuticles, vascular tissue and fusain or black clots remained. The cuticles and conducting tissues must have been separated from the remaining matter. Only two cuticles and many remains of conducting tissues were discovered and mounted in glycerine jelly slides (No. 697/1-2). Some vascular tissue was mounted on stub 129 for observation under a scanning electron microscope.

\section{DESCRIPTIONS}

\subsection{Cuticle with polygonal cells (PI. 1, figs. A, B).}

A fragment of cuticle shows irregular polygonal cells, $60-130 \mu \mathrm{m}$ long and $30-70 \mu \mathrm{m}$ wide. Anticlinal walls are straight, the periclinal wall surface is covered by small circular depressions caused by weathering or corrosion (Pl. 1, fig. B).

Remarks: Cuticles with polygonal cells are common and are often seen on the adaxial side of pteridosperm and cycad fronds. Seed integuments of these plant groups have similar cuticular patterns (CLEAL et al., 2010). Perhaps strong corrosion could explain the fact that only two cuticles were preserved in the present sample. The less cutinised cuticles were probably destroyed during fossilisation and/or subsequently during the maceration.

\subsection{Cordaitalean cuticle (PI. 1, figs. C, D)}

The cuticle has a typical cordaitalean cell pattern: parallel oriented tetragonal cells with papillae. The cells are 35-100 $\mu \mathrm{m}$ long and $9-17 \mu \mathrm{m}$ wide. The papillae occur in a row in numbers of $4-8$ on the cell surface.

Remarks: Cuticles with this pattern of cells have so far not been observed in any group other than the Cordaitales. In particular, elongated cells with papillae are typical for cordaitaleans growing in peat-forming conditions (ŠIMŮNEK \& FLORJAN, 2013a,b; ŠIMŮNEK \& HALDOVSKÝ, 2015). As there are no preserved stomata, the cuticle is difficult to accommodate into the system of dispersed cuticles within the Cordaitales. The genus Cordaites UNGER is based on leaf shape and venation; and lately also on epidermal characteristics obtained from "in situ" leaf fragments (ŠIMŮNEK \& HALDOVSKÝ, 2015 and ŠIMU゚NEK, 2019). Dispersed cordaitalean cuticles tend to be difficult to correlate with "in situ" cuticles, so an "artificial" taxonomy of cordaitalean cuticles was developed (ŠIMU゚NEK \& FLORJAN, 2013b). In this scheme, two fossil-genera were erected: Cordaadaxicutis ŠIMU゚NEK \& FLORJAN, 2013b and Cordaabaxicutis ŠIMŮNEK \& FLORJAN, 2013b. The presence of stomata is necessary for classification into either of these genera, but they were not observed in this case. Nevertheless, it is evident that this fragment belongs to the cordaitaleans.

A very similar cuticle has been described by LIU et al. (1998) from the Lower Permian of the Zhungeerqi locality in Inner Mongolia in China and named Cordaites neimengensis LIU et al. 1998. A comparison of the stomata is not possible, but the cell dimensions are comparable: $62.4-144 \mu \mathrm{m}$ in length and 9.7-16.8 $\mu \mathrm{m}$ in width. Stomatal rows are separated by $1-10$ rows of cells. On the fragment described here, there are 22 cell rows without any stomatal row.

Another very similar cuticle comes from the Lower Permian of the Döhlen Basin in Germany (BARTHEL, 1962), described as Cordaites sp. Typ 2 BARTHEL, 1962. The common features are tetragonal cells with papillae. BARTHEL (1962) presents cell dimensions as $50-100 \mu \mathrm{m}$ long and $6-15 \mu \mathrm{m}$ wide. The stomatal rows are separated by up to 15 cell rows.

Papillae are relatively common on cordaitalean cuticles isolated from coal samples, especially on abaxial cuticles (WARTMAN, 1969; ŠIMU゚NEK \& FLORJAN, 2013a, b; ŠIMŮNEK \& HALDOVSKÝ; 2015, ŠIMŮNEK, 2019). The cuticles in these papers have similar ordinary epidermal cells, and the stomata are arranged into stomatal rows. It is strange that neither stoma nor stomatal rows have been identified in the present fragment. Up to now, papillae were not observed on adaxial cuticles. Also Cordaites neimengensis LIU et al. does not have papillae on its adaxial cuticle. Therefore. at present this cuticle fragment can only be classified as a "cordaitalean cuticle". Despite the absence of stoma and stomatal rows being preserved, we consider this cuticle to represent an abaxial one.

\subsection{Conducting tissue (PI. 2)}

Tracheids of secondary xylem are preserved. Most fragments contain one or two layers of tracheids. (Pl. 2, Fig. C, det 1). The tracheids have bordered pits in radial longitudinal section. Oval bordered pits are arranged tightly one to another and have preserved a closed porus $(\mathrm{Pl} .2 \mathrm{~B}, \mathrm{E})$. The tracheid pitting is mostly biseriate to quadriseriate in a tracheid width of $60-100 \mu \mathrm{m}(\mathrm{Pl}$. 2, Figs A, C).

Remarks: Tracheids with polyseriate pitting and tight arrangements of the bordered pitting are typical for cordaitaleans (FALCON-LANG et al., 2005; NOLL et al., 2005; BURE ̌́, 2011; MENCL et al., 2013). Based on these studies, cordaitalean secondary xylem contains tracheids with (1)-2-3-4-(5) series of oval bordered pits, which can have a nearly hexagonal shape and compact arrangement. The studied tracheids fully correspond to this description. No other type of tracheid has been observed.

\section{DISCUSSION}

WARTMANN (1969) studied cordaitalean papillae from a biological perspective. He came to the conclusion that these papillae are not "real papillae" as they are only papillous thickenings of the cutin on cells, and not specialised cells covered with cutin. WARTMANN's (1969) cordaitalean cuticles also came from a 
coal seam, so this feature cannot be considered as a xerophytic indicator. WARTMANN (1969) wrote about "physiological xerophytness" caused by a specific condition in the peat bog, e.g. a lack of nitrogen in the soil. These papillae occur in cordaitalean cuticles prepared from coals of early Westphalian to early Permian strata (ŠIMU゚NEK, 2019; ŠIMU゚NEK \& FLORJAN, 2013a, b; WARTMANN, 1969; BARTHEL, 1962 and LIU et al., 1998). All these papillae have the same nature and have been observed only on the abaxial leaf surfaces.

The coal from Wuda contained very few cuticles and no palynomorphs but conducting tissues. This is strange because palynomorphs are usually preserved in coal. As palynomorphs usually do not need as long a time for maceration as cuticles and conducting tissue they may have been destroyed during the maceration process, thus explaining their absence in the sample. $\mathrm{Cu}$ ticles are sometimes very common, sometimes rare and in some types of coal they are not present at all - a situation that has not been satisfactorily explained. It does not depend only on coal maturity, because it was sometimes not possible to obtain cuticles from not highly coalified coal. In such a case megaspores usually dominate (in the Westphalian). Wuda is another locality with rare cuticle content, but the well preserved conducting tissue shows that the maceration was done correctly. Unlike this cuticle from a coal, "in situ" cordaitalean cuticles separated from tuff specimens do not have papillae and belong to another species. Secondary xylem fragments found in the coal sample contain bi- to quadriseriate tracheids that are typical of cordaitaleans, which is in accordance with the cordaitalean cuticle observed in the coal.

\section{CONCLUSION}

Two cuticles from Wuda were studied. One shows polygonal cells, and probably represents a pteridosperm or cycad, either from an adaxial cuticle of a frond or possibly a seed integument cuticle. The other has papillate tetragonal, parallel-oriented cells, and is considered to be an abaxial cuticle of some cordaitalean plant. Because stomata are absent, this cuticle cannot be assigned to the cordaitalean dispersed cuticle classification. However, it can be compared with Cordaites neimengensis LIU et al. and Cordaites sp. Typ 2 BARTHEL, Secondary xylem with bi- to quadriseriate tracheids confirms the presence of cordaitalean wood in the Wuda locality.

\section{ACKNOWLEDGEMENT}

The authors thank J. VOTOČKOVÁ-FROJDOVÁ (Academy of Science, Prague) and M. LIBERTÍN (National Museum, Prague) for the coal sample from the Wuda locality. This research was undertaken within the scope of the Czech Geological Survey internal assignment 323100 .

\section{REFERENCES}

BARTHEL, M. (1962): Zur Kenntnis inkohlter Blätter der Gattung Cordaites Presl.Hall. Jb. f. Mitteldt. Erdg., 4, 37-39.

BUREŠ, J. (2011): Silicified cordaite and conifer wood in the sediments of the Líně Formation of the Pilsen Carboniferous Basin.- Erica 18, 179-198 (in Czech).
CLEAL, C.J., ZODROW, E.L. \& MASTALERZ, M., (2010): An association of Alethopteris foliage Trigonocarpus ovules and Bernaultia-like pollen organs from the Middle Pennsylvanian of Nova Scotia, Canada.- Palaeontog. Abt. B, 283, 73-97.

FALCON-LANG, H.J. \& BASHFORTH, A.R. (2005): Morphology, anatomy, and upland ecology of large cordaitalean trees from the Middle Pennsylvanian of Newfoundland.- Rev. Palaeobot. Palynol., 135, 223-243.

HALLE, T.G. (1927): Palaeozoic plants from central Shansi.- Palaeontol. Sin., Ser. A, 2 (1), 1, 1-316.

HE, X., ZHU, M. \& FAN, B. (1995): The Late Palaeozoic Stratigraphic Classification, Correlation and Biota From Eastern Hill of Taiyuan City, Shanxi Province [in Chinese with English summary].- Jilin University Press, Changchun. 149 p.

LEE, H.-H., (1963): Fossil plants of the Yuehmenkou Series, North China [in Chinese with English summary].- Palaeontol. Sin., 148, 1-185.

LIU, Z.-H., GENG, B.-Y, WANG, S.-J. \& LI, C.-S. (1998): On Cordaites neimengensis sp. nov from Lower Permian of Zhungerqi, Inner Mongolia, China.- Acta Bot. Sin., 40/4, 383-388.

MENCL, V., BUREŠ, J. \& SAKALA, J. (2013): Summary of occurrence and taxonomy of silicified Agathoxylon-type of wood in late Paleozoic basins of the Czech Republic.- Folia Mus. Rer. natur. Bohem. occident. Geol. et Paleobiol., 47/1-2, $14-26$.

NOLL, R., RÖSSLER, R. \& WILDE, V. (2005): 150 Jahre Dadoxylon - Zur Anatomie fossiler Koniferen- und Cordaitenhölzer aus dem Rotliegend des euramerischen Florengebietes.- Veröffentlichungen des Museums für Naturkunde Chemnitz, 28, $29-48$.

PFEFFERKORN, H.W. \& WANG, J. (2007): Early Permian coal-forming floras preserved as compressions from the Wuda District (Inner Mongolia, China).- Int. J. Coal Geol., 69, 90-102.

SHEN, G., (1995): Permian floras. In: LI, X., et al. (eds.), Fossil Floras of China Through the Geological Ages (Engl. edition).- Guangdong Science and Technology Press, Guangzhou, 127-223.

SHEN, G., WANG, Y., WANG, J., LIU, H. \& ZHANG, S., (1996): Tectonic implications of Permian floras in China.- Palaeobotanist, 45, 324-328.

ŠIMŮNEK, Z. \& BUREŠ, J. (2015): Dispersed cuticles and conducting tissue of Sphenophyllum BRONGNIART from the Westphalian D of Kalinovo, Donets Basin, Ukraine.- Geol. Croat., 68/1, 1-9. doi: 10.4154/gc.2015.01

ŠIMU゚NEK, Z. \& FLORJAN, S. (2013a): An artificial system of dispersed cordaitalean cuticles from the Upper Silesian Basin (Pennsylvanian, Poland) and its application to dispersed cordaitalean cuticles from the Intrasudetic Basin (Pennsylvanian, Czech Republic). Lethaea rossica. Rossijskij paleobotanicheskij zhurnal - The Russian Journal of Palaeobotany. Paleobotanicheskij vremenik, Neperiodicheskie prilozhenie k zhurnalu, 1, 53-65.

ŠIMU゚NEK, Z. \& FLORJAN, S. (2013b): The Pennsylvanian cordaitalean dispersed cuticles from the Upper Silesian Basin (Poland).- Rev. Palaeobot. Palynol., 197, 26-49.

ŠIMU゚NEK, Z. \& HALDOVSKÝ, J. (2015): Contribution to the knowledge of Cordaites species from the Kladno-Rakovník Basin, Middle Pennsylvanian (Bolsovian) Czech Republic.- Geol. Croat., 68/2, 93-111. ISSN 1330-030X. doi: 10.4154/ gc. 2015.11

ŠIMŮNEK, Z. (2019): The earliest evidence of cordaitalean cuticles from coal in the Pennsylvanian of Europe (Langsettian, Upper Silesian Basin, Czech Republic).Rev. Palaeobot. Palynol., 261, 81-94. https://doi.org/10.1016/j.revpalbo.2018.11.007

WANG, J., LIU, L. \& ZHANG, Y. (2007): Pennsylvanian through the end of Permian continental sequences in Shanxi and an Early Permian autochthonous flora in tuff in Inner Mongolia.- Guidebook for Field Excursion A2. XVI Int. congr. on Carboniferous and Permian, Nanjing, $24 \mathrm{p}$.

WANG, J. \& SHEN, G. (1996): Permian phytogeography of China.- Palaeobotanist, $45,272-277$.

WANG, J., ZHANG, Q. \& SHEN, G. (1999): Permian phytogeography of Cathaysian flora in China in the light of cluster analysis [in Chinese with English summary].Acta Palaeontol. Sin., 38, 530-543.

WARTMANN, R. (1969): Studie über die papillen-förmigen Verdickungen auf der Kutikule bei Cordaites an Material aus dem Westphal C des Saar-Karbons.- Argumenta Palaeobot., 3, 199-207. 

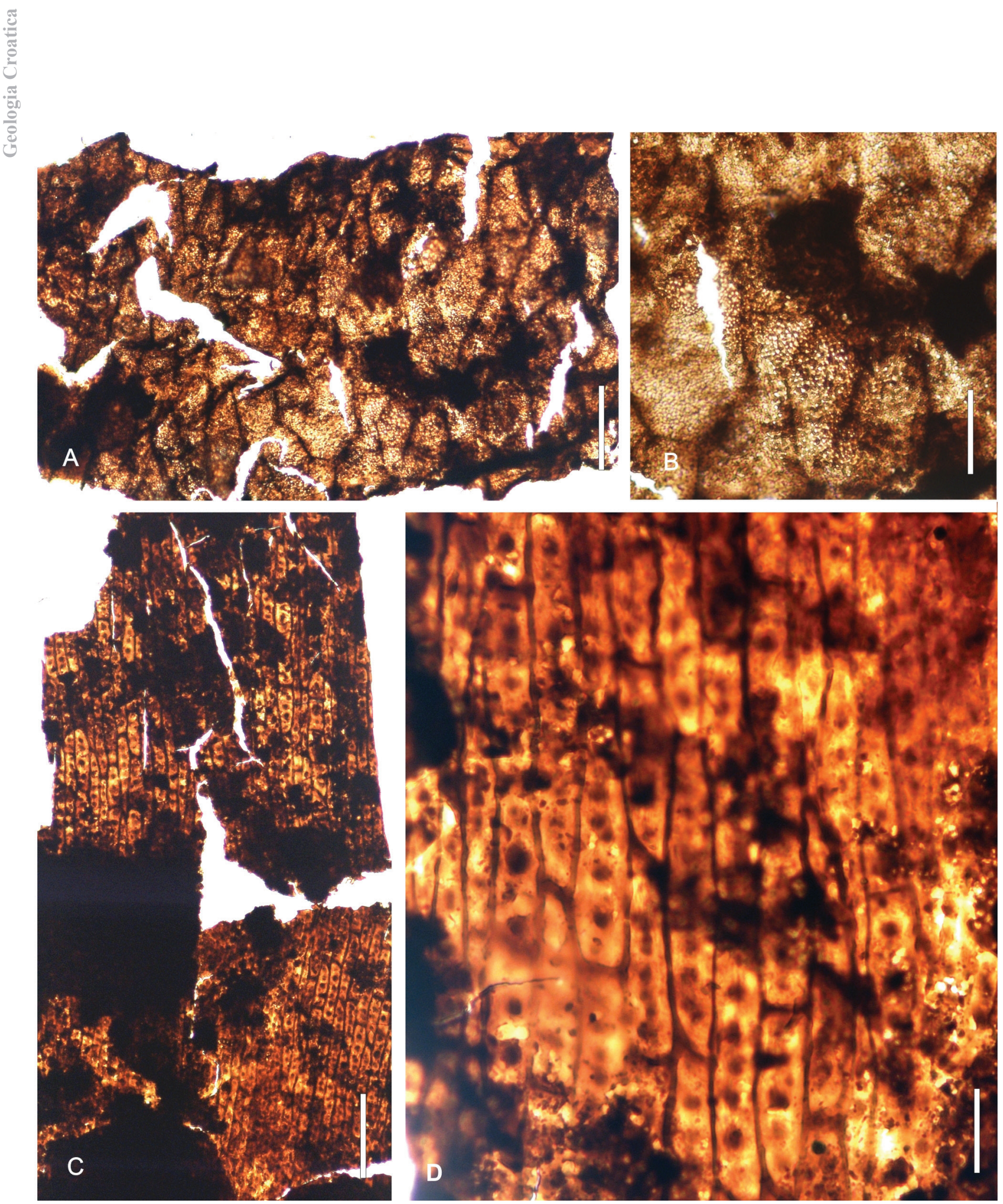

Plate 1

A, B - Dispersed cuticle with polygonal cells, note the strong corrosion on Fig. B. Slide 697/1. A - scale bar $=100 \mu \mathrm{m}$; B - scale bar $=50 \mu \mathrm{m}$.

C, D - Dispersed cordaitalean cuticle. D - Close up of cells with papillae. Slide $697 / 2$. C - scale bar $=100 \mu \mathrm{m} ; \mathrm{D}$ - scale bar $=25 \mu \mathrm{m}$. 

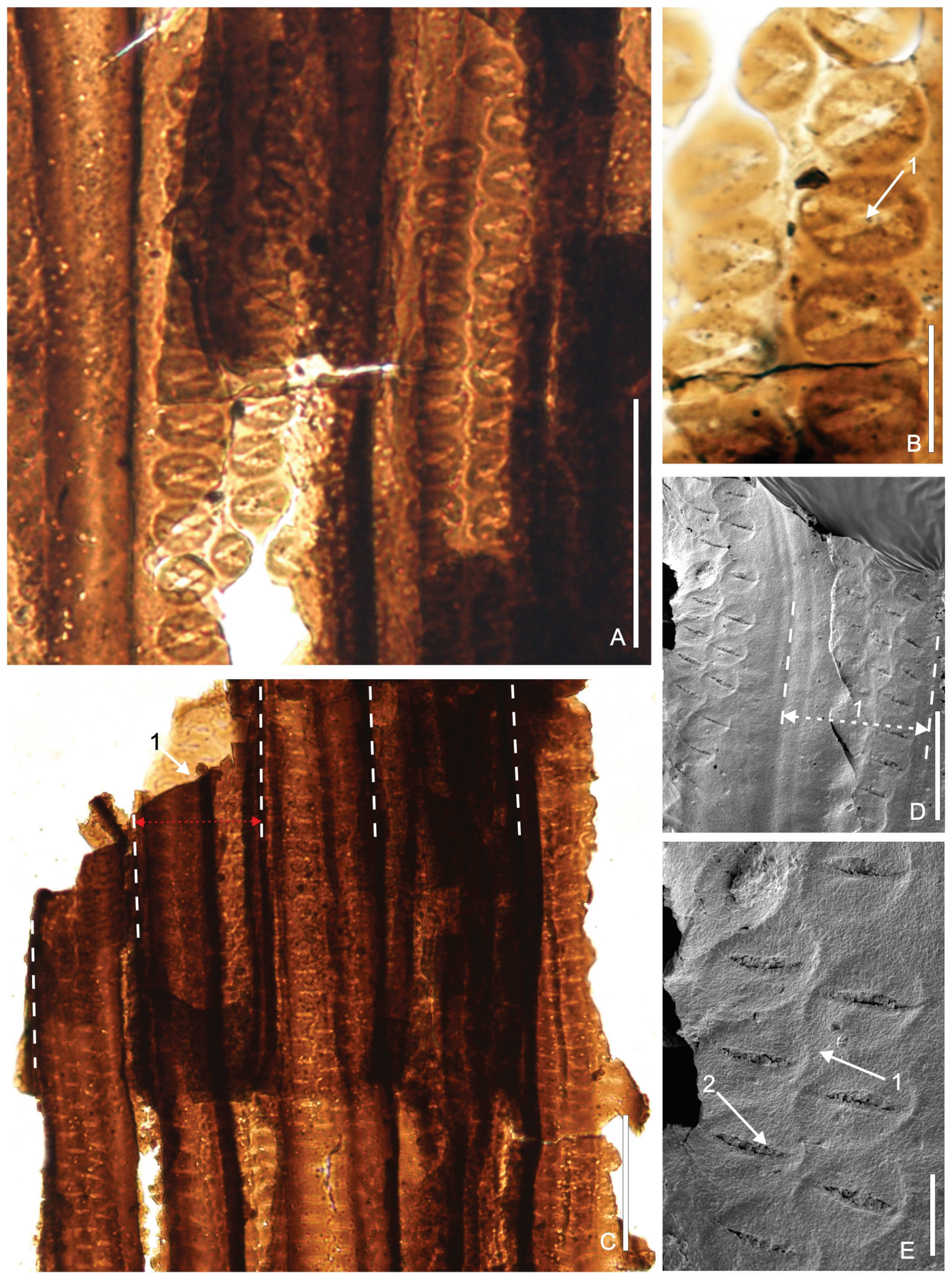

Plate 2

Conducting tissue, A-E slide 697/2; F and G SEM stub 129.

A - Tracheids in radial longitudinal section with bi- and triseriate wall pitting. Scale bar $=80 \mu \mathrm{m}$.

B - Close up of round tracheid pitting arranged closely to one another. 1 - Closed porus is preserved on both side of the bordered pit. Scale bar $=20 \mu \mathrm{m}$.

C - Tracheid layer with tri- and quadriseriate wall pitting. 1 - border covering two tracheid layers and delimitation of individual tracheids. Scale bar $=87 \mu \mathrm{m}$

D - Surface of bordered pits. 1 Delimitation of tracheid width with triseriate pitting. Scale bar $=40 \mu \mathrm{m}$.

E - Close up of tracheid surface with bordered pitting. 1 - The bordered pits adhere tightly to one another. 2 - Porus is in the closed condition. Scale bar $=10 \mu \mathrm{m}$. 